\title{
Evidence for mutation being the source of the abnormal gene for plasma cholinesterase
}

\author{
R. T. EVANS and P. J. MAGILL \\ Biochemistry Department, Southmead Hospital, Bristol
}

\begin{abstract}
Summary. Results of cholinesterase, dibucaine and fluoride numbers, and scoline hydrolysis rates are presented in a family found to have normal, silent and abnormal genes for plasma cholinesterase. Five sibs, confirmed by red cell grouping and tissue typing, have been shown to possess a cholinesterase pattern which cannot be explained on the basis of accepted theories of inheritance. In view of this it is suggested that, in this family, a mutation has occurred from a normal or silent gene to an abnormal gene.
\end{abstract}

Soon after the introduction of succinyl dicholine (Scoline, Suxamethonium) as a short acting muscle relaxant in 1949 it was recognized that the brief period of action was due to its rapid breakdown by plasma cholinesterase (acetyl choline acyl hydrolase E.C. 3.1.1.8) (Bovet-Nitti, 1949). Subsequently it was discovered that some patients are peculiarly sensitive to the drug, muscle relaxation lasting for several hours rather than the normal 2-3 minutes (Evans et al, 1952). Lehmann and Ryan (1956) showed that this sensitivity could often be attributed to the inheritance of two co-dominant genes for an abnormal enzyme, which was later demonstrated to be unable to hydrolyse scoline at pharmacological concentrations (Davies, Marton, and Kalow, 1960).

The observations of Kalow and Genest (1957) that this protein could be differentiated from the normal on the basis of a simple biochemical test represented a considerable advance in the laboratory detection of sensitive individuals. These workers showed that the abnormal enzyme was resistant to inhibition by the local anaesthetic agent dibucaine and devised the concept of the dibucaine number (DN), which was defined as the percentage inhibition of the enzyme by $10^{-5} \mathrm{M}$ dibucaine. The $\mathrm{DN}$ is $80 \pm 4$ for normal enzyme, but only $20 \pm 4$ for enzyme from persons homozygous for the abnormal gene. An intermediate group of subjects were observed to have dibucaine numbers of $60 \pm 5$ and these were shown to be heterozygotes. These observations have since been confirmed (Johnson and

Received 19 November 1973.
Whitehead, 1965; Fishtal, Evans, and Chapman, 1972).

Other selective inhibitors are now well recognized, the most important of which is fluoride, and a gene has been described which is responsible for the production of enzyme specifically resistant to fluoride inhibition (Harris and Whittaker, 1961).

In 1962, profound Scoline sensitivity was reported in a patient having no detectable plasma cholinesterase activity (Liddell, Lehmann, and Silk, 1962). Several other cases have since appeared in the literature (Doenicke et al, 1963; Szeinberg et al, 1966; Heyworth and Firth, 1967). These patients are believed to be homozygous for the so-called 'silent gene' but evidence is at present equivocal as to whether there is a complete failure of enzyme synthesis, or whether enzyme is present, but in an inactive form (Goedde, Gehring, and Hofmann, 1965; Hodgkin et al, 1965). The incidence of this condition is low, approximately 1 in 300,000 in Caucasians, but it has been observed to be very high in some isolated Eskimo communities where it is present in an estimated $1.5 \%$ of the population (Gutsche, Scott, and Wright, 1967).

Four allelic genes determining plasma cholinesterase are now recognized:

Eu-the normal or usual gene.

$\mathrm{Ea}$ - the abnormal, dibucaine-resistant gene.

$\mathrm{Ef}$ - the fluoride resistant gene.

Es-the silent gene.

All the expected genotypes corresponding to 
these genes have now been described (Simpson and Kalow, 1964; Lehmann and Liddell, 1969).

In this communication we would like to report a family in which usual and silent genes have been shown to be present, but in which the principal interest lies in the appearance of the dibucaineresistant abnormal enzyme under circumstances which make it unlikely that the parents of the family possessed the gene for this enzyme.

\section{Methods}

Plasma cholinesterase was assayed on the Astrup micro $\mathrm{pH}$ apparatus as described by Johnson and Whitehead (1965). Dibucaine numbers were determined according to the method of Kalow and Genest (1957) and fluoride numbers by the method of Harris and Whittaker (1961), both using benzoyl choline as substrate. Scoline hydrolysis rates were measured by the method of Fishtal et al (1972).

Red cell grouping was determined by colleagues in the South West Regional Blood Transfusion Centre and lymphocyte antigens by colleagues in the National Tissue Typing Laboratory in this hospital, by a standard technique using two-stage cytotoxicity.

\section{Results and Discussion}

The propositus, a 47-year-old male, presented with an apnoea lasting two and a half hours following the administration of $80 \mathrm{mg}$ scoline. On investigation no plasma cholinesterase activity was demonstrable, and so his immediate family were also examined.

The relevant part of the pedigree is shown in Fig. 1, and the results of investigations on the propositus and his five sibs in Table I. It is important to note that the presence of the abnormal gene in II.10 is confirmed by its presence in all of his three children.

Regrettably both parents of the propositus are deceased, but the parental genotypes for plasma cholinesterase cannot be derived from the genotypes of the offspring without the exclusion of either II.2, in which case genotypes would be EuEs and EaEs, or II.10, in which case they would be EuEs and EuEs.

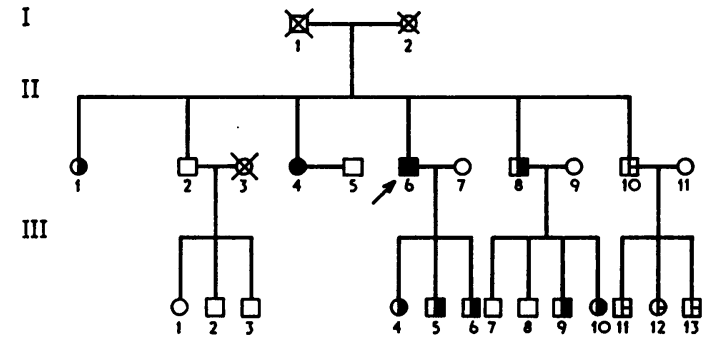

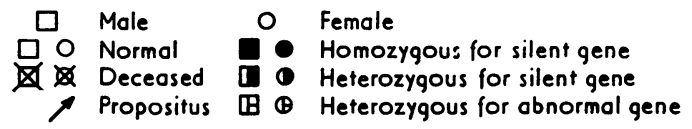

Fig. 1. Pedigree showing results of laboratory investigations on the propositus and his immediate family.

A potential explanation of this phenomenon is, of course, non-consanguinity of one or more of the six children and, in order to attempt to confirm or deny this, they were further investigated by determination of their lymphocyte antigens and red cell groups. These results are summarized in Table II.

The red cell and lymphocyte antigens found demonstrate, with a high degree of probability, that five of the six sibs are the children of two parents only. The presence of a W18 antigen on the lymphocytes of II.8 makes the explanation of his parentage more difficult, but even if he were to be excluded from the group, the problem of identifying the parental genotypes still remains.

There are four possible explanations of these findings.

1. That despite the evidence of lymphocyte and red cell antigens the five sibs in question are the children of more than two parents. It is impossible to eliminate this explanation entirely, but an approximate computation based on the known incidence of these antigens makes the likelihood less than 1 in 500 .

2. That the usual, abnormal and silent genes are non-allelic. There is at present no evidence to

TABLE I

RESULTS OF INVESTIGATIONS ON THE PROPOSITUS (II.6) AND HIS FIVE SIBS

\begin{tabular}{|c|c|c|c|c|c|c|c|}
\hline Subject & Age (yr) & Sex & $\begin{array}{c}\text { Plasma } \\
\text { Cholinesterase } \\
\text { (iu/l.) }\end{array}$ & $\begin{array}{l}\text { Dibucaine } \\
\text { Number }\end{array}$ & $\begin{array}{l}\text { Fluoride } \\
\text { Number }\end{array}$ & $\begin{array}{c}\text { Scoline } \\
\text { Hydrolysis } \\
\text { Rate }\end{array}$ & $\begin{array}{l}\text { Suggested } \\
\text { Genotype }\end{array}$ \\
\hline $\begin{array}{l}\text { II.1 } \\
\text { III.2 } \\
\text { II.4 } \\
\text { II.6 } \\
\text { II.8 } \\
\text { II.10 }\end{array}$ & $\begin{array}{l}53 \\
51 \\
48 \\
47 \\
46 \\
28\end{array}$ & $\begin{array}{l}\mathrm{F} \\
\mathbf{M} \\
\mathrm{F} \\
\mathbf{M} \\
\mathbf{M} \\
\mathbf{M}\end{array}$ & $\begin{array}{c}214 \\
432 \\
\text { Less than } 10 \\
\text { Less than } 10 \\
123 \\
210\end{array}$ & $\begin{array}{l}81 \\
81 \\
\frac{7}{74} \\
63\end{array}$ & $\begin{array}{l}72 \\
71 \\
\frac{70}{70} \\
61\end{array}$ & $\begin{array}{l}0 \cdot 103 \\
0 \cdot 162 \\
0 \cdot 001 \\
0 \cdot 024 \\
0 \cdot 079 \\
0 \cdot 115\end{array}$ & $\begin{array}{l}\text { EuEs } \\
\text { EuEu } \\
\text { EsEs } \\
\text { EsEs } \\
\text { EuEs } \\
\text { EuEa }\end{array}$ \\
\hline
\end{tabular}


TABLE II

RESULTS OF LYMPHOCYTE AND RED CELL ANTIGENS ON THE PROPOSITUS (II.6) AND HIS FIVE SIBS

\begin{tabular}{|c|c|c|c|c|c|c|}
\hline & II.1 & II.2 & II.4 & II.6 & II.8 & II.10 \\
\hline HL-A phenotype & $1,10,8,13$ & $10,7,13$ & $1,7,8$ & $1,7,8$ & $1,8, \mathrm{~W} 18$ & $1,10,8,13$ \\
\hline Probable HL-A genotype & $1,8 / 10,13$ & $10,7 / 10,13$ & $1,7 / 1,8$ & $1,7 / 1,8$ & $1,8 / 1, \mathbb{W} 18$ & $1,8 / 10,13$ \\
\hline$\overline{\mathrm{ABO}}$ & A1B & $\mathbf{B}$ & A1 & A1 & A2 & A1 \\
\hline MNS & MS & MN & MS & MNS & MS & $\mathbf{N}$ \\
\hline $\mathbf{P}$ & P2 & P1 & P1 & P1 & P1 & P1 \\
\hline Probable Rhesus genotype & $\mathrm{CDe} / \bar{c} \mathrm{de}$ & $\mathrm{CDe} / \bar{c} \mathrm{de}$ & $\overline{\mathrm{cDE}} / \overline{\mathrm{cde}}$ & $\mathrm{CDe} / \bar{c} \mathrm{de}$ & $\overline{c d e} / \bar{c} \mathrm{de}$ & $\overline{\text { cde/cide }}$ \\
\hline Lewis & $\operatorname{Le}(a-b-)$ & $\operatorname{Le}(a-b+)$ & $\operatorname{Le}(a-b+)$ & $\operatorname{Le}(a-b+)$ & $\operatorname{Le}(a-b+)$ & $\operatorname{Le}(a-b-)$ \\
\hline Duffy & $\mathrm{Fy}^{\mathrm{a}+}$ & $\mathrm{Fy}^{\mathrm{a}+}$ & $\mathrm{Fy}^{\mathrm{a}+}$ & $\mathrm{Fy}^{\mathrm{a}+}$ & $\mathrm{Fy}^{\mathrm{a}+}$ & $\mathrm{Fy}^{\mathrm{a}+}$ \\
\hline
\end{tabular}

support such a hypothesis while the great majority of published pedigrees are readily explained on the basis of three allelic genes.

3. The presence of a suppressor gene. The observed results could be explained on the basis of a suppressor gene if one accepted that, during the early part of the parent's reproductive life, the abnormal gene was suppressed and thus appeared as a silent gene. One would then need to conclude that at some time after the birth of II. 6 and before the birth of II.10 the influence of the suppressor gene was removed, allowing the abnormal gene to express itself. However, in their paper on 'the silent gene' in which they discussed at length the possibility of a supressor gene being responsible for lack of enzyme activity in patients possessing the silent gene, Simpson and Kalow (1964) concluded that the presence of such a gene was unlikely. We have seen no recent report in the literature which could give rise to a change in the conclusions of these authors.

4. A mutation: either (a) from Ea or Es to Eu in the early part of the parent's reproductive life resulting in the EuEu genotype in II.2, or (b) from Eu or Es to Ea in the later part of the parent's reproductive life which would account for the presence of the abnormal gene in II.10.

If it is accepted that the members of this family group are indeed sibs then the possibility of a mutation having occurred must be a strong one. This being so, then a mutation from Eu or Es to Ea must be more likely than from Ea or Es to Eu since II.10 is 16 years younger than his nearest brother and at the time of his birth his mother was 46 years old.

In view of the known relationship between genetic defects and high maternal age it would seem that any mutation would be more likely to occur during the conception of II.10 than his brother II.2. Also, had the abnormal gene been present in one of the parents it might reasonably have been expected to appear in more than one of the six children.

If one accepts this explanation of the origin of the abnormal gene in this family, then such mutations could represent the source of the abnormal enzyme in the general population, for which no other explanation has been forthcoming.

\section{REFERENCES}

Bovet-Nitti, F. (1949). Degradazione di alcune sostanze curarizzanti per azione di colinesterasi. Rendiconti Istituto Superiore di Sanità, 12, 138-157.

Davies, R. O., Marton, A. V., and Kalow, W. (1960). The action of normal and atypical cholinesterase of human serum upon a series of esters of choline. Canadian fournal of Biochemistry and Physiology, 38, 545-551.

Doenicke, A., Gürtner, T., Kreutzberg, G., Remes, I., Spiess, W., and Steinbereithner, K. (1963). Serum cholinesterase anenzymia: report of a case confirmed by enzyme-histochemical examination of liver-biopsy specimen. Acta Anaesthesiologica Scandinavica, 7, 59-68.

Evans, F. T., Gray, P. W. S., Lehmann, H., and Silk, E. (1952). Sensitivity to succinylcholine in relation to serum-cholinesterase. Lancet, 1, 1229-1230.

Fishtal, A., Evans, R. T., and Chapman, C. N. (1972). An original approach to the diagnosis of scoline induced apnoea. Fournal of Clinical Pathology, 25, 422-426.

Goedde, H. W., Gehring, D., and Hofmann, R. A. (1965). On the problem of a 'silent gene' in pseudocholinesterase polymorphism. Biochimica et Biophysica Acta, 107, 391-393.

Gutsche, B. B., Scott, E. M., and Wright, R. C. (1967). Hereditary deficiency of pseudocholinesterase in Eskimos. Nature, 215, 322323.

Harris, H. and Whittaker, M. (1961). Differential inhibition of human serum cholinesterase with fluoride: recognition of two new phenotypes. Nature, 191, 496-498.

Heyworth, R. and Firth, H. M. J. (1967). Silent gene for serumcholinesterase. Lancet, 2, 1422.

Hodgkin, W. E., Giblett, E. R., Levine, H., Baur, W., and Motulsky, A. G. (1965). Complete pseudocholinesterase deficiency: genetic and immunologic characterization. Fournal of Clinical Investigation, 44, 486-492.

Johnson, J. K. and Whitehead, T. P. (1965). Rapid estimation of serum cholinesterase activity using the Astrup micro equipment. fournal of Clinical Pathology, 18, 435-440.

Kalow, W. and Genest, K. (1957). A method for the detection of atypical forms of human serum cholinesterase. Determination of dibucaine numbers. Canadian fournal of Biochemistry and Physiology, 35, 339-346.

Lehmann, H. and Liddell, J. (1969). Human cholinesterase (pseudocholinesterase): genetic variants and their recognition. British fournal of Anaesthesia, 41, 235-244. 
Lehmann, H. and Ryan, E. (1956). The familial incidence of low pseudocholinesterase level. Lancet, 2, 124.

Liddell, J., Lehmann, H., and Silk, E. (1962). A silent pseudocholinesterase gene. Nature, 193, 561-562.

Simpson, N. E. and Kalow, W. (1964). The 'silent' gene for the serum cholinesterase. American fournal of Human Genetics, 16 180-187.

Szeinberg, A., Pipano, S., Ostfeld, E., and Eviatar, L. (1966). The silent gene for serum pseudocholinesterase. Fournal of Medical Genetics, 3, 190-193. 